\title{
INNOVATIVE TRENDS IN GEOGRAPHY FOR PUPILS WITH MILD INTELLECTUAL DISABILITY
}

\author{
Monika Šulovská ${ }^{1}$, Alica Vančová ${ }^{2}$
}

\begin{abstract}
This contribution focuses on applying Google Maps in educating pupils with mild intellectual disability. To achieve this, we design and submit an evaluation tool for measuring the pupils' skills in the Google Maps environment, inspired by Bloom digital taxonomy. We also assess the level of achieved skills of pupils with mild intellectual disability by comparing mapping with other variables in the geographic competences area. The study focuses on the result of research carried out within the VEGA no. 1/0789/14 project. The study also identifies the positive effect of a geographical information system (GIS) on the learning of intact pupils. To the surprise of the authors, the portal of Google Maps appealed to these participants to the extent that they continued to use it for self-study at their homes.
\end{abstract}

JEL Classification Numbers: I210, DOI: http://dx.doi.org/10.12955/cbup.v4.785

UDC Classification: 376

Keywords: pupils with mild intellectual disability, geography education, google maps.

\section{Introduction}

One ponders the true necessity for geographical education of pupils, with a light degree of intellectual disability, in the 21 st century. According to a requirement for new concepts in education, the education context of geography should correspond to the physical world. Up-to-date mapping technologies are considered most important and beneficial for this practice. To determine a user's movement, location, direction, or speed, a global positioning system (GPS) is currently used. In geography, GPS can be used for determining geographical coordinates and cardinal points, as well as measuring the travelled route over the terrain. Today, almost every cell phone has a GPS and this allows pupils to work with global positioning and achieve skills, even when not at school. For graphic visualization of maps in an electronic environment, a geographical information system (GIS) is mainly used. According to Kubaliaková and Balážovič (2010) and Kalaš, Kabátová, Brestenská, and Winczer (2013), GIS represents the new generation of informative application of geography in the society. Sudolská (2004) defined GIS as a computer system orientated towards processing geographical data, which are presented through maps. It is a professional program used for representation and analysis of large amounts of data, bound to a certain area. These systems include their own database for processing and visualization and according to Kalaš et al. (2013), a database is an important part of GIS. In education, GIS helps to develop geographical (spatial) literacy, which is defined as the ability to distinguish location and topology, i.e., the spatial relationships of map points and their attributes.

\section{Geographical Information Systems Application to the Subject Geography}

With the emergence of the Internet and new technologies, there has been an increase in online interactive maps that are not only visual and attractive for users, but also, in terms of their interactivity, are much more interesting than classic paper maps. However, paper maps in education of pupils with intellectual disability remain of value. Notwithstanding, changes due to the development of new web technologies, resulting in easy access to large amounts of information (geographical data and map services), need solid application in the school of geography. Furthermore, GIS is absent in current education conception of pupils with a light degree of intellectual disability and there is also uncertainty as to whether it will be appropriately incorporated into the new-design of school-books and methodical manuals.

Google Maps (2016) is currently the most popular map service, globally, and contains high quality satellite and terrain maps (accessed by changing the display mode in the map window at the bottom

\footnotetext{
${ }^{1}$ Monika Šulovská, Faculty of Education, Department of Special Education, Comenius University in Bratislava, Slovakia, sulovskamonika@gmail.com

${ }^{2}$ Alica Vančová, Faculty of Education, Department of Special Education, Comenius University in Bratislava, Slovakia, vancova.alica@gmail.com
} 
left). After entering a location in the search box, a map and data of time and weather of the searched location are displayed (Figure 1). This information is extremely interesting for pupils with intellectual disability as they do not understand time zones, but with the given information they can determine the time shift and also compare data of several countries.

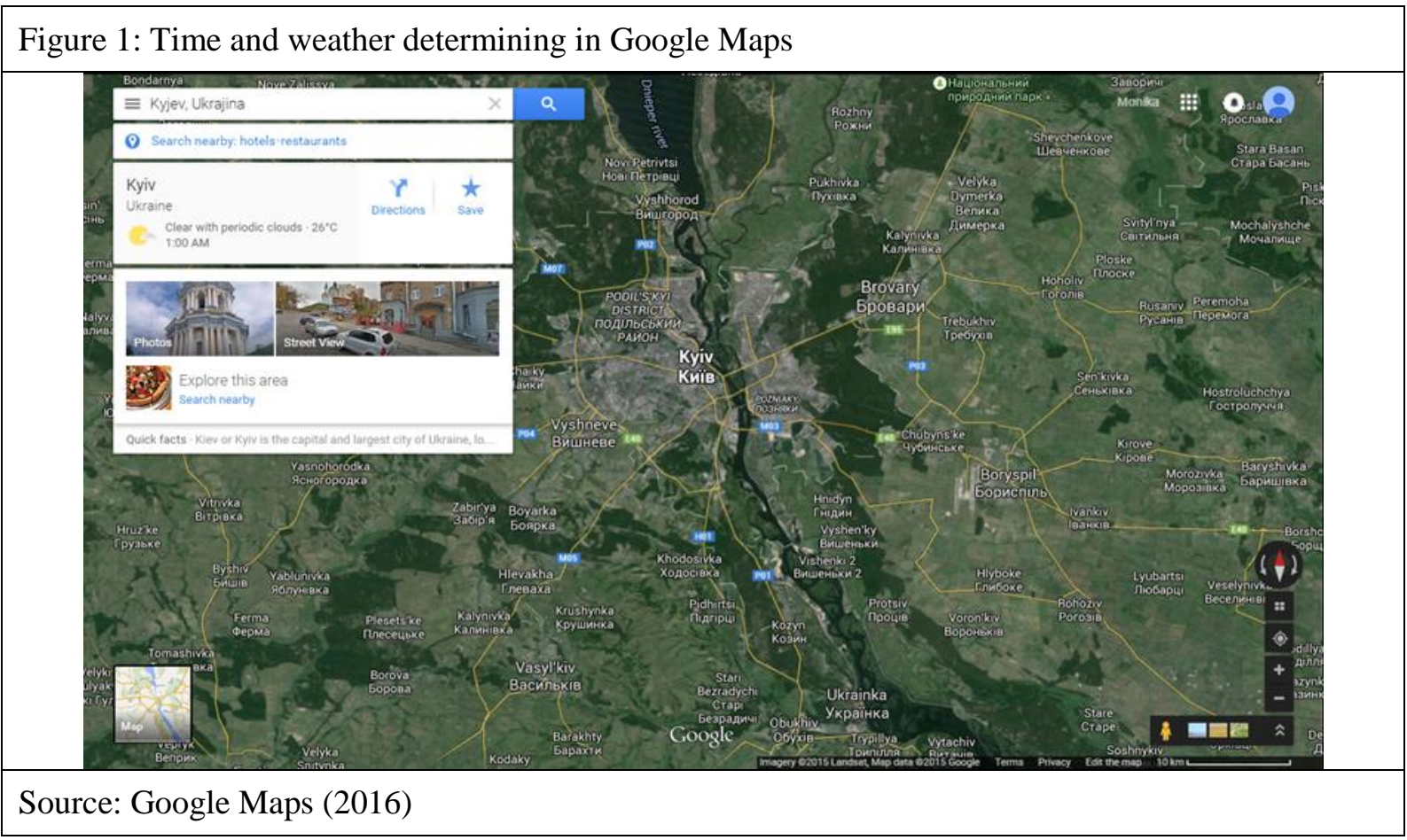

A Google Maps' user can apply a 'loop', resize the map window, or search by entering a name of a location. Next to the search box (Figure 2), there are other applications for mapping a trip travelled by car, public transportation, bike, or by walking. It is somewhat difficult for a pupil with intellectual disability to imagine the distance in hundreds or thousands of kilometers. A positive for helping the imagination of the pupil is that with the distance shown for travel between two sites in Google Maps, also indicates travel time. In addition, every function in the menu is represented by an icon that suggests the purpose and manner of its use. The map view (zoom level) can be changed with a large slider, appearing in the right part of the map area. On the left side appears contextual information that can be hidden to gain more area for the map. Using the computer keyboard key, F11, the Internet service can be switched do full-screen mode for more effective visualization.

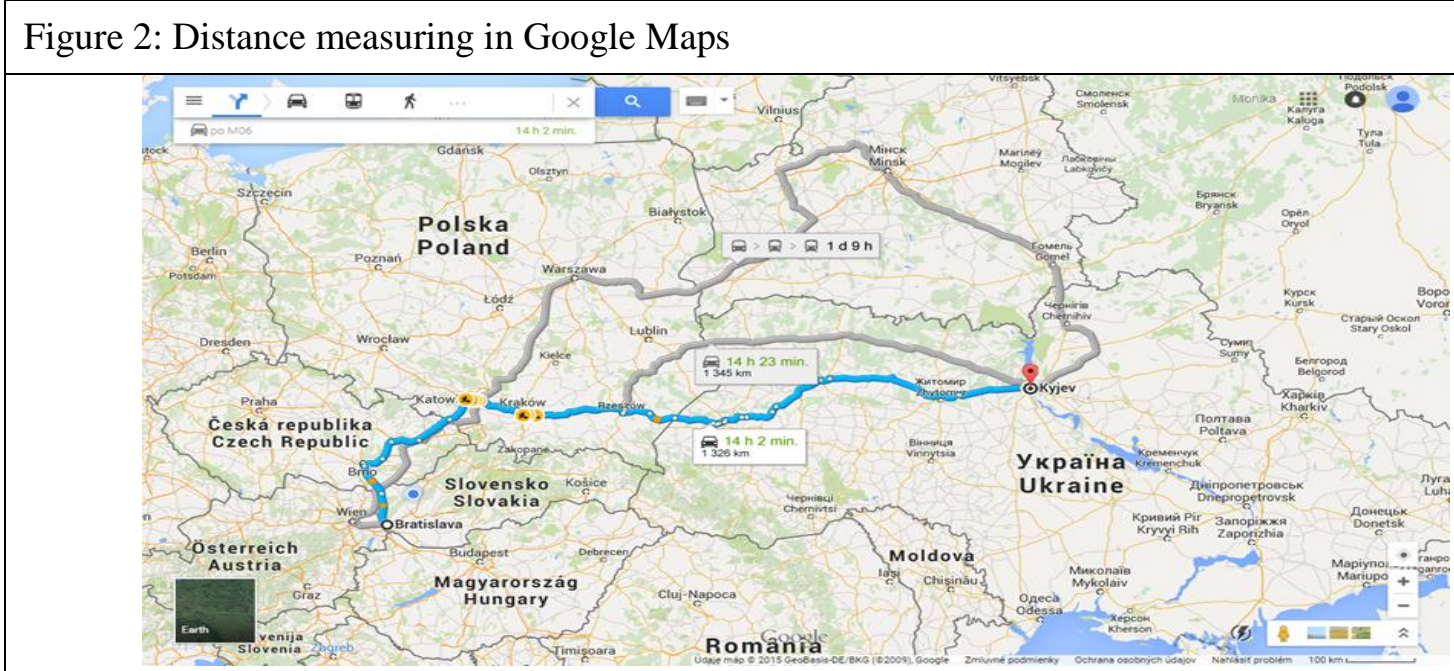

Source: Google Maps (2016) 
In addition, Google Maps allows virtual walks through streets, almost anywhere in the world. In October 2012, Google Enterprise added Slovakia to their 'Street View' program. Street View mode allows walks in distant localities and this can provide pupils with an almost authentic feeling of visiting the site in person. According to Churches (2009), there is a resurgence of map use. Moreover, in identifying the need for brain compatible education (Kovaliková \& Olsenová, 1996) with this resurgence, geography becomes more interesting, understandable, and easier for pupils.

In Google Maps (2016), one can find a site of interest and then pose as the yellow character, activated from the navigation panel, to wander over the given site. Areas captured in Street View become highlighted in blue. One can set the mode to a classic map, which has a feature below the Street View indicating the relevant street. Street View allows a 360-degree range of view. Operation of this service is intuitive and highly motivating for pupils. However, as shown in Figure 3, an impressive benefit of Street View mode is that it helps bridge the gap in spatial orientation by combining the traditional view of a map with authenticity of the site from various perspectives. This feature was highlighted by Churches (2009) in his educational portal.

\section{Figure 3: Virtual excursion in Google Street View}

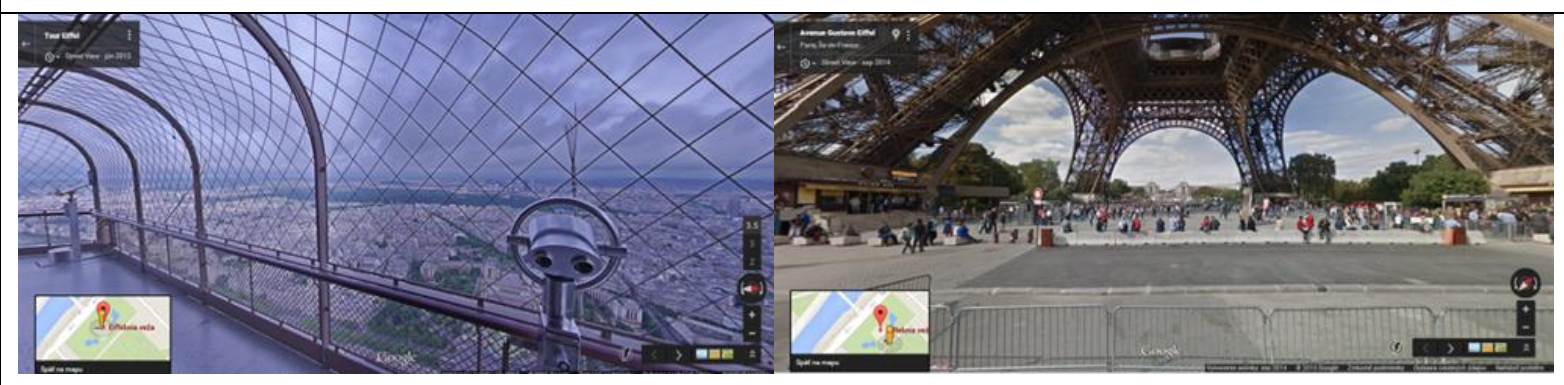

Source: Google Maps (2016)

On February 27, 2014, Google Enterprise updated Google Street View with five Slovak caves and added several panoramic images, including historic and natural wonders.

Hyperlapse, is an application that Google Street View introduced in 2013. Entering an arbitrary initial or final point in a map, it provides a video presentation of the route. When needing to focus on a certain place during a trip, one can move the relevant icon to the target, and thereby allow tracking from different aspects. This would greatly facilitate the work of teachers who search for videos on the Internet to visualize certain areas of curriculum (compare the videos on the Internet, which are mostly on YouTube and copyrighted, subjected to comments, and many times with low quality imagery or ineffective length of presentation). With this application, teachers and pupils with a light degree of intellectual disability can 'shoot' a video of the area in a few seconds. Visualization is very important in the education of pupils with intellectual disability as they do not understand numbers referring to an area of the country. Map Fight (2016) is a simplistic application (Figure 4) that allows users to visually compare the area of two countries.

Measuring GIS skills of a pupil with light degree of intellectual disability in Google Maps area is of interest. With spread of maps and GIS on the Internet, it is inevitable to acquire (not only traditional skills of searching for a site on a map) many skills referring to the use of a map. Skills acquired by working with maps are also frequently used in private or professional life. A capability of reading the necessary information from maps is the basic condition for geographical literacy. According to the author, Walbert (2010), it is somewhat difficult for intact children, aged between 7 and 8 years, to read a map. Possibly, with age they will naturally achieve this spatial understanding. However, one ponders how this is achieved in pupils with an intellectual disability, who are unable to work on the abstract level and have insufficient spatial perception.

A search of the Slovak literature for testing the geo-information skills of pupils, provided portfolios of intact pupils (in Slovak basic schools of secondary grammar schools) that represented more long-term pupils' work, directly or indirectly incorporating GIS (developing projects and presentations). Consultations with geography didactics from Comenius University in Bratislava, indicated a lack of 
evaluation tools, specially designed for measuring the skills of pupils in the area of GIS use, at that time.

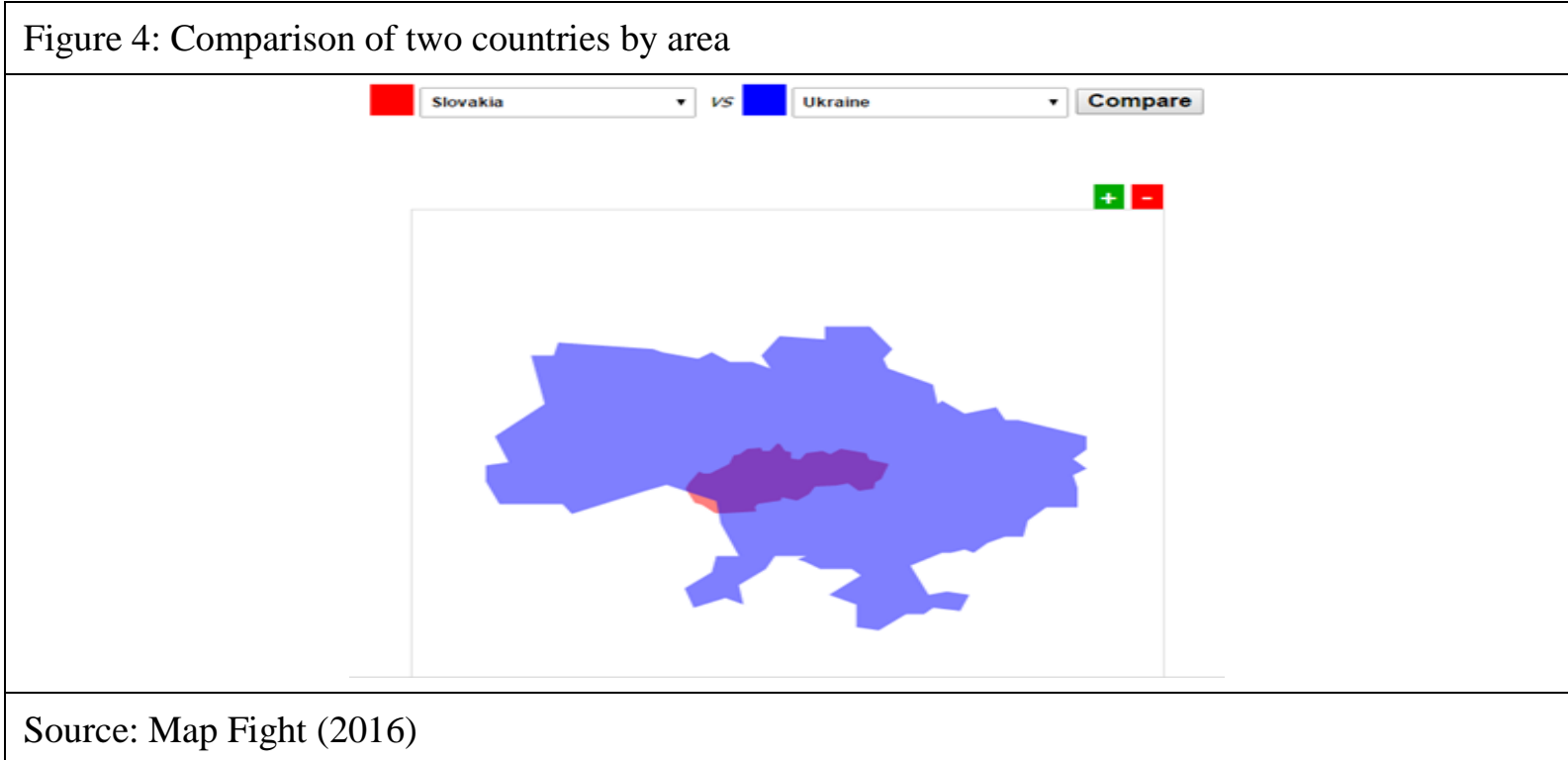

Figure 5: Evaluation tool for measuring the skills of pupils in the area of Google Maps Street View

\begin{tabular}{|c|c|}
\hline \multicolumn{2}{|r|}{ APPLICATION, EDITING AND SHARING BY GOOGLE MAPS AND STREETVIEW } \\
\hline $\mathbf{0}$ & $\begin{array}{l}\text { Pupils cannot move between various views and map styles. } \\
\text { No ability to zoom pictures and maps. } \\
\text { No use of localization tools. } \\
\text { No use of navigation tools. } \\
\text { No understanding of whole localization and scale }\end{array}$ \\
\hline 1 & $\begin{array}{l}\text { Pupils move with difficulties between various views and map styles. } \\
\text { Ability to zoom pictures and maps. } \\
\text { Use only some of the localization tools including shifting map, Street View a search fields } \\
\text { Use only some of the navigation tools including tools on screen and movements with mouse for panning, turning, zooming and } \\
\text { moving. } \\
\text { Very poor understanding of whole localization and scale. }\end{array}$ \\
\hline 2 & $\begin{array}{l}\text { Pupils can move between various views and map styles. } \\
\text { Ability to zoom pictures and maps } \\
\text { Navigate through various tools including shifting map, Street View, hover view (views from above) and search fields. } \\
\text { Use only some of the navigation tools including tools on screen and movements with mouse for panning, turning, zooming and } \\
\text { moving. } \\
\text { Poor understanding of whole localization and scale. }\end{array}$ \\
\hline 3 & $\begin{array}{l}\text { Pupils can move between various views and map styles, choose appropriate view for the given task. } \\
\text { Navigate through various tools including shifting map, Street View, hover view, search fields, embedded pictures, links and } \\
\text { videos. } \\
\text { Use some of the navigation tools including tools on screen and movements with mouse for panning, turning, zooming and } \\
\text { moving. } \\
\text { Measure distance between two objects through the tool "route". } \\
\text { Find the car travel time. Find the walk travel time. } \\
\text { Poor understanding of whole localization and scale. }\end{array}$ \\
\hline 4 & $\begin{array}{l}\text { Pupils can move between various views and map styles, choose appropriate view for the given task. } \\
\text { Navigate through various tools including shifting map, Street View, hover view, search fields, embedded pictures, links and } \\
\text { videos. } \\
\text { Use some of the navigation tools including tools on screen and movements with mouse for panning, turning, zooming and } \\
\text { moving. } \\
\text { Measure distance between two objects through the tool "route". } \\
\text { Find the car travel time. Find the current time and weather of searched place. } \\
\text { Able to make the link of map and share it in email. } \\
\text { Limited understanding of whole localization and scale. }\end{array}$ \\
\hline
\end{tabular}

Source: Churches (2009) 
In the foreign literature, Churches (2009) who, using the Bloom digital taxonomy, designed a schedule of evaluation criteria for the GIS service, Google Maps. This approach places pupils at the highest level when they are able to search and localize key words, make annotations by hotspots, and share these hotspots and maps with their contemporaries.

Regarding the possibilities of a pupil with a light degree of intellectual disability, however, a possible achievable goal is another point. Thus, it is important to focus on a finer sequence of these skills. Figure 5 shows the final evaluation criteria, modified for pupils with mild intellectual disability, and used in the research of Sulovská (2014).

\section{Results of the Measuring GIS Skills in Pupils with Mild Intellectual Disability in Google Maps}

Churches (2009) concluded that using GIS improved the understanding and skills of pupils, thereby increasing their self-confidence. Similarly, in psychological studies, Churches (2009) confirmed efficiency of image visualization in comparison with textual information. In addition, the author highlighted GIS effects on the development of spatial thinking. Patterson (2007) also summarized the positive effect of GIS on the learning of pupils outside of school. Also, Černá, Šiška, Strnadová, Kainová, and Titzl (2015) ascribed great importance to GIS in the area of spatial orientation.

In our research (Šulovská, 2014), to globally assess the geographical competences of a pupil with a light degree of intellectual disability, we tested their knowledge using digital autotests and conceptual maps; their skills orientation on digital maps and GIS in Google maps; and attitudes to school lessons of geography by a scaled questionnaire. To depict the area of greatest shift we used a radar diagram to distinguish the changes (Figure 6).

Figure 6: Searched variables in three participants depending on phases*
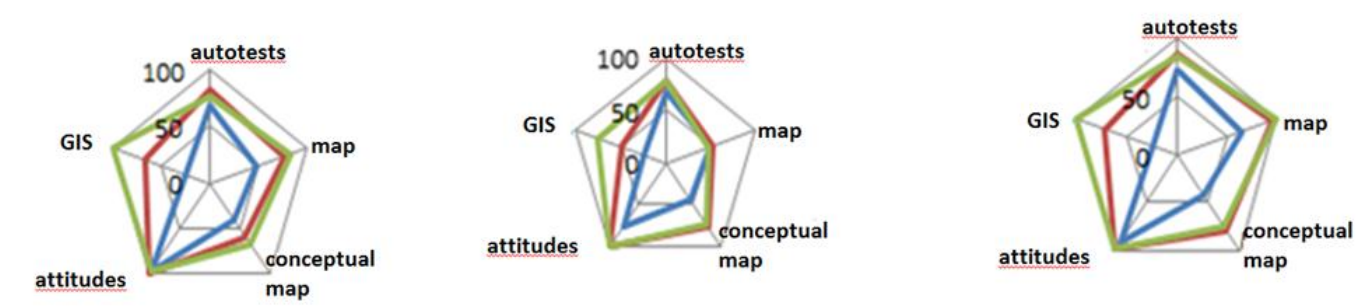

*Blue: phase of 7 lessons without use of information technologies; Red: phase of 8 lessons with use of information technologies; Green: phase of 7 lessons without use of information technologies

Source: Šulovská (2014)

The diagrams in Figure 6 display three participants who were 7th class pupils and participated in all 22 lessons of geography. They were tested in three phases: 1) seven lessons without use of information technologies (blue); eight lessons with use of information technologies (red); and another seven lessons without use of information technologies (green). During all lessons and for every pupil, we collected research material in the form of 110 tests. In every lesson, we introduced only one European country to a pupil and always tested the pupil at the end of the lesson, only on that location. The radar diagram of the phases showed visible increases of values on the evaluation scale corresponding to the area of testing GIS skills. As shown in Figure 5, pupils were evaluated on the basis of four degrees of managing the task. In our research, on improving objectivity, we evaluated this skill in conformity on two members of the research team.

The diagrams in Figure 6 suggest that the achieved skills persevered during the learning phase without information technologies being strengthened through practice. Bajo and Vašek (1994) inferred this case was the fifth highest phase of skills development where a pupil displays high quality performance in various conditions and situations (in our research, the various conditions represented several countries and information about them). Churches (2009) stated "This finding is not unusual, especially as the intervention introduces new skill for the participant. Once the skill acquired, it is difficult to 
return in back" (p. 128). We acknowledge that this change was unexpected. Švarcová (2011, p. ??) wrote that pupils with intellectual disability "forget quickly acquired skills and usually are not able to use them in practice in time and appropriately" we rather supposed that absence of strengthening the skill on the lessons would result in its partial weakening or loss. Patterson (2007) also declared the positive effect of GIS on the learning of intact pupils even when away from school. However, we had not considered that working in the portal Google maps would appeal to the participants to the extent that they would use it for self-study at their homes. This finding emerged from data triangulation involving a test, interview with participant, and their parent. A study examining the results of acquired skills over a longer period would be of further interest.

However, we propose that by mapping the home computer environments of the participants, in the case where every family owns a computer connected to the Internet, will not significantly weaken the skill of our participants. Overall, we concur with the findings of Černá et al. (2015) that working with the GIS service of Google Maps is highly attractive to participants and increases their motivation to learn new things, as was reflected in our study with their self-study that resulted in positive grades in tests of GIS skills in Google Maps after a phase of learning about information technologies. We conclude this area with the opinions of Jakabčic and Požár (1995) and Vančová (2014), who referred to the popularity of the subject as hobbies of pupils with mild intellectual disability. Similarly, regarding the research result, Padberg (2010) stated that although teaching through the Internet cannot guarantee better learning results, its innovative approach can develop pupils' creativity, independence, curiosity, and positive attitude towards their school and learning. Thus, adequate interest in the activity (work in Google Maps) directly reinforces the results of teaching.

In general, our research was limited by sample size. The impact or importance of GIS depends on the goal of the education and the role it has in geography of the time. Where geography education is about learning competencies that are necessary in today's world, the role of GIS is irreplaceable.

\section{Conclusion}

The purpose of this contribution was to choose the typical environments, certified in our pedagogic practice, that would help increase the efficiency of educating pupils with intellectual disability. To the brief characteristics of the most important features, there were added possibilities of their application in educating pupils with mild intellectual disability. We presented details of the GIS portal of Google Maps, because it was crucial for our research. In the contribution, we endeavored to provide the most important findings of the work, with information and emphasis on the relationship of these findings within the context of geography. It is comprehensible that its optimality for the teacher is highly relevant. Not only due to rapid development of technologies, but, in general, the problem of measuring competences, to date, is the least elaborated category of evaluation because of its relative novelty. However, it is supposed that the importance of working with information in education is ongoing and therefore, we recommend further research in this area.

Efforts to streamline the teaching of geography, in line with the possibilities, capabilities, and interest of pupils with intellectual disability is reflected, not only in efforts to innovate, but also in optimizing teaching methods. In this stream, an important place is occupied by finding new measurement tools that allow deeper and more reliable cognition of the current state of pupils' knowledge, skills, and attitudes.

\section{References}

Bajo, I., \& Vašek, Š. (1994). Pedagogika mentálne postihnutých (Psychopédia) [Education mentally handicapped (Psychopedie)]. Bratislava: Sapientia.

Černá, M., Šiška, J., Strnadová, I., Kainová, T., \& Titzl, B. (2015). Česká psychopedie: Speciální pedagogika osob s mentálním postižením. Praha: Karolinum [Czech psychopedy: Special Education of persons with mental disabilities. Prague: Karolinum].

Churches, A. (2009, April 1). Blooms Digital Taxonomy. Retrieved from http://edulibpretoria.files.wordpress.com/2009/05/blooms-digital-taxonomy.pdf

Google Maps (2016). Retrieved from https://www.google.sk/maps

Jakabčic, I., \& Požár, L. (1995). Všeobecná patopsychológia. Patopsychológia mentálne postihnutých [General patopsychológia. Patopsychológia mentally disabled]. Bratislava: Iris.

Kalaš, I., Kabátová, M., Brestenská, B., \& Winczer, M. (2013). Premeny školy v digitálnom veku [School transformation in the digital age]. Bratislava: SPN. 
Kovaliková, S., \& Olsenová, K. (1996). Integrované tematické vyučovanie [Integrated thematic teaching]. Bratislava: Faber. Kubaliaková, K., \& Balážovič, L. (2010). Využitie informačných a komunikačných technológií v predmete geografia pre základné školy. Košice: elfa s.r.o. [Use of ICT in the subject of geography for elementary schools. Košice Elfa Ltd.]

MapFight (2016). Retrieved from http://mapfight.appspot.com/

Padberg, S. (2010). Der Einsatz des Internets im Geographieuntericht. Meinungsbilder und

Unterrichtsbeobachtungen..Frankfurt am Main: Peter Lang Verlag [The use of the Internet in geography lesson . Opinion photos Unterrichtsbeobachtungen. Frankfurt am Main: Peter Lang Publishing]

Patterson, Todd. C. (2007). Google Earth as a (Not Just) Geography Education Tool, Journal of Geography, 106:4, 45-152. DOI: 10.1080/00221340701678032. Retrieved from http://www.tandfonline.com/doi/pdf/10.1080/00221340701678032

Sudolská, M. (2004). Geografické informačné systémy - moderný pomocník učitel’a [Geographic information systems modern assistant teacher]. BIGECHE 5, 45-55, Retrieved from http://www.mcpo.sk/downloads/Publikacie/BIGECHE/BIGECHE5.pdf

Šulovská, M. (2014). The use of information and communication technologies in an innovative and effective educational process in geography for intellectual disability students. Dissertation thesis, Comenius University, Faculty of Pedagogy, Special Pedagogy Department. Dissertation thesis supervised by: Professor PaedDr. Alica Vančová, CSc. Bratislava: Faculty of Education UK, 2014. 217p.

Švarcová, I. (2011). Mentální retardace. Praha: Portál [Mental retardation. Prague: Portal].

Vančová, A. (2014). New methods of stimulation, rehabilitation and correction of motor disabilities and optimisation of anomalous psychomotor development as results of transfer of knowledge in neuroscience to theory and practice of special education focused on children with CNS damage. International Journal of Multidisciplinary Thought, 4, 287-305.

Walbert, D. (2010). Map Skills and Higher Order Thinking. Retrieved from http://www.learnnc.org/lp/editions/mapping/6410 